\title{
Accumulation of ${ }^{60} \mathrm{Co},{ }^{90} \mathrm{Sr},{ }^{137} \mathrm{Cs},{ }^{238} \mathrm{U}$ and transuranic elements by berry shrubs in forest ecosystems of the Yenisei river basin
}

\author{
D. Dementyev and A. Bolsunovsky \\ Institute of Biophysics, Siberian Branch of the Russian Academy of Sciences, \\ Krasnoyarsk 660036, Russia, \\ e-mail: dementyev@gmail.com
}

\begin{abstract}
The study investigates accumulation of radionuclides in 5 species of berry shrubs in forests of the Yenisei River basin (the Krasnoyarskii Krai, Russia). Activity concentrations of ${ }^{60} \mathrm{Co},{ }^{90} \mathrm{Sr},{ }^{137} \mathrm{Cs},{ }^{238} \mathrm{U}$ and transuranic elements in aboveground organs of the shrubs have been determined and their transfer factors calculated. Analysis of the calculated TFs shows that shrubs concentrate ${ }^{90} \mathrm{Sr}$ more effectively than other study elements $(\mathrm{TF}=0.25-1.9)$. The highest concentration of ${ }^{137} \mathrm{Cs}$ is recorded in the berries and leaves of Ribes nigrum and Rubus idaeus. For these species, the range of ${ }^{137} \mathrm{Cs}$ TFs $(0.006-0.027)$ overlaps with the range of ${ }^{238} \mathrm{U}$ TFs (0.004-0.018). For the aboveground parts of Ribes nigrum, TFs for transuranic radionuclides (0.01-0.056) are similar to or higher than the TFs for ${ }^{238} \mathrm{U}$ and ${ }^{137} \mathrm{Cs}$.
\end{abstract}

\section{INTRODUCTION}

Among terrestrial ecosystems contaminated with artificial radionuclides is the portion of the Yenisei River basin affected by the operation of the Mining-and-Chemical Combine (MCC), which produced weapons-grade plutonium. There are very few data on radionuclide accumulation in forest ecosystems of these areas, and they mainly concern contamination of trees, as the main object of forest management. Other components of forest ecosystems, such as shrubs, which are also involved in accumulation and redistribution of radionuclides, have not been investigated until now [1,2].

The purpose of this study is to estimate the transfer of artificial radionuclides, including transuranic ones, into berry shrubs via roots.

\section{METHODS}

We studied radionuclide accumulation by the berry shrubs Ribes hispidulum (Jancz.) Pojark, Ribes nigrum L., Rosa majalis Herrm., Rubus idaeus L., and Viburnum opulus L. growing in the forests. Plant and soil samples were collected in the areas contaminated by radionuclides contained either in MCC aerosol releases or in its liquid effluents. Samples were collected from the following sites (Fig. 1): the background sampling site "Krasnoyarsk", with radioactivity due to global fallouts only; "Zheleznogorsk" (66 km downstream of Krasnoyarsk), "Atamanovo (village)" (88 km), and "Balchug (village)" (98 km) - the sites contaminated due to global fallouts and MCC aerosol discharges; and "Atamanovo (island)" and "Balchug (island)" - the Yenisei floodplain sites contaminated by watertransported artificial radionuclides. Investigations were performed from 2004 to 2010.

Samples of berry shrubs collected during the fruit-bearing season were split into branches, leaves, and berries, which were dried at $65^{\circ} \mathrm{C}$. The dry samples were weighed and ashed in a muffle furnace at $450^{\circ} \mathrm{C}$. The activity concentrations of the $\gamma$-emitting nuclides in the samples were measured on a Canberra $\gamma$-spectrometer (USA) coupled to a GX2320 23\% hyper-pure germanium detector. The $\gamma$-spectra were processed using the CANBERRA GENIE-2000 software (USA). Concentration of ${ }^{238} \mathrm{U}$ 


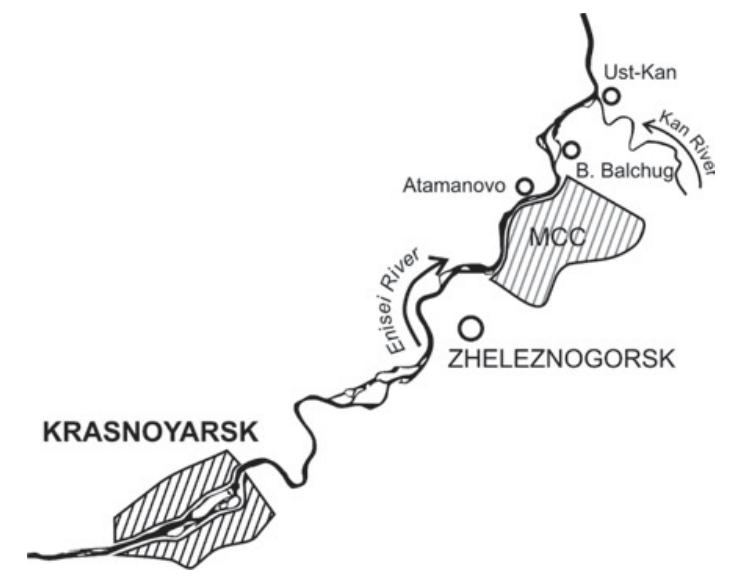

Figure 1. Diagrammatic map of the Krasnoyarsk Territory (Russia), showing villages and towns near which samples were collected.

in the samples was determined using the instrumental neutron-activation analysis at Tomsk Polytechnic University (Tomsk, Russia).

Radiochemical investigations of the samples of shrub species and the soil collected from a floodplain site ("Atamanovo (island)") to determine $\alpha$-emitting isotopes $\left({ }^{238} \mathrm{Pu},{ }^{239,240} \mathrm{Pu},{ }^{241} \mathrm{Am}\right.$, and ${ }^{243,244} \mathrm{Cm}$ ) and a $\beta$-emitting isotope, ${ }^{90} \mathrm{Sr}$, were performed at the Centre for Information Processes and Technologies of the "RADON" Scientific \& Industrial Association (Moscow). Methods and instrumentation for the analysis of samples for radiostrontium and transuranium elements were described elsewhere [3]. All activity concentrations of radionuclides were calculated for air dry mass of the samples.

\section{RESULTS AND DISCUSSION}

The contamination of the soils in the study area is not uniform owing to the complex topography of the area and the various routes of radionuclide entry. To date, the following radionuclides are recorded in the floodplain soils downstream of the MCC: ${ }^{60} \mathrm{Co},{ }^{137} \mathrm{Cs},{ }^{152,154} \mathrm{Eu},{ }^{90} \mathrm{Sr}$, uranium, and isotopes of transuranic elements: ${ }^{238} \mathrm{Pu},{ }^{239,240} \mathrm{Pu},{ }^{241} \mathrm{Am},{ }^{243,244} \mathrm{Cm}$ [3]. ${ }^{137} \mathrm{Cs}$ concentration in the samples of Rosa majalis, Rubus idaeus, and Viburnum opulus collected at the study sites ranged from $0.2 \mathrm{~Bq} / \mathrm{kg}$ to $64 \mathrm{~Bq} / \mathrm{kg}$. Samples of aboveground phytomass from the floodplain soils contained ${ }^{60} \mathrm{Co}-$ up to 8.4 $\mathrm{Bq} / \mathrm{kg}$; no other artificial $\gamma$-emitting radionuclides were found to accumulate in the phytomass. ${ }^{137} \mathrm{Cs}$ alone was detected in the study berry shrubs collected from the sites contaminated by aerosol-delivered radionuclides, and its activity was near the limit of detection. In Ribes nigrum, Rosa majalis, and Viburnum opulus, the maximum activity concentration of ${ }^{137} \mathrm{Cs}$ was recorded in the berries - up to $64 \mathrm{~Bq} / \mathrm{kg}$. In Ribes hispidulum and Rubus idaeus leaves, the highest ${ }^{137} \mathrm{Cs}$ activity concentration was $51 \mathrm{~Bq} / \mathrm{kg}$.

The shrubs Rubus idaeus and Ribes nigrum, which accumulated the greatest amounts of ${ }^{137} \mathrm{Cs}$, were used in a detailed study of radionuclide accumulation, employing radiochemical analysis [2,3]. Analysis of the aboveground parts of Ribes nigrum showed that activity concentrations of ${ }^{60} \mathrm{Co}$ and ${ }^{137} \mathrm{Cs}$ were 1.5-3 times higher in the leaves than in the branches, which can be accounted for by conductive function of branches during the period of active plant growth. The distribution of ${ }^{137} \mathrm{Cs}$ in the organs of Rubus idaeus is similar to its distribution in Ribes nigrum. Radiochemical analysis showed that in Ribes nigrum ${ }^{90} \mathrm{Sr}$ was mainly accumulated in the leaves (up to $60 \mathrm{~Bq} / \mathrm{kg}$ ), while the berries contained the lowest ${ }^{90} \mathrm{Sr}$ concentrations - not higher than $3.8 \mathrm{~Bq} / \mathrm{kg}[2]$. 
Table 1. Transfer factors of radionuclides to different parts of the shrubs for the sites contaminated by waterdelivered radionuclides.

\begin{tabular}{|l|l|l|l|l|l|}
\hline TFs & ${ }^{40} \mathrm{~K}$ & ${ }^{60} \mathrm{Co}$ & ${ }^{90} \mathrm{Sr}$ & ${ }^{137} \mathrm{Cs}$ & ${ }^{238} \mathrm{U}$ \\
\hline \multicolumn{7}{|c|}{ Ribes nigrum } \\
\hline Branches & 0.48 & 0.01 & 0.9 & 0.009 & 0.018 \\
\hline Leaves & 0.94 & 0.02 & 1.9 & 0.029 & 0.011 \\
\hline Berries & 1.19 & $<$ DL & 0.25 & 0.027 & 0.004 \\
\hline \multicolumn{7}{|c|}{ Rubus idaeus } \\
\hline Branches & 0.69 & <DL & n.d. & 0.006 & 0.008 \\
\hline Leaves & 1.34 & <DL & n.d. & 0.008 & $<$ DL \\
\hline Berries & 1.20 & $<$ DL & n.d. & 0.010 & $<$ DL \\
\hline
\end{tabular}

Note: DL - detection limit; n.d. - not determined.

The Yenisei River floodplain is contaminated by artificial radionuclides $\left({ }^{60} \mathrm{Co},{ }^{90} \mathrm{Sr},{ }^{137} \mathrm{Cs}\right.$, etc.), which are either products of stable isotope activation or ${ }^{238} \mathrm{U}$ fission products. ${ }^{238} \mathrm{U}$ and transuranic elements ( $\mathrm{Pu}, \mathrm{Am}$, and $\mathrm{Cm}$ isotopes) may enter the environment together with artificial radionuclides. Measurements of ${ }^{238} \mathrm{U}$ in Rubus idaeus and Ribes nigrum showed that in Ribes nigrum, this isotope was mainly accumulated in the branches and leaves. ${ }^{238} \mathrm{U}$ concentration in the aboveground organs ranged from $0.012 \mathrm{mg} / \mathrm{kg}$ to $0.14 \mathrm{mg} / \mathrm{kg}$. Samples collected in the most heavily contaminated floodplain site, "Atamanovo (island)", were analyzed for transuranic elements [3]. In the aboveground phytomass of Ribes nigrum, the highest concentrations of isotopes of transuranic elements were recorded in the leaves (up to $0.4 \mathrm{~Bq} / \mathrm{kg}$ of ${ }^{239,240} \mathrm{Pu}$ and up to $0.05 \mathrm{~Bq} / \mathrm{kg}$ of ${ }^{243,244} \mathrm{Cm}$ ) and berries (up to $0.88 \mathrm{~Bq} / \mathrm{kg}$ of ${ }^{239,240} \mathrm{Pu}$ and up to $0.03 \mathrm{~Bq} / \mathrm{kg}$ of ${ }^{243,244} \mathrm{Cm}$ ).

The capacities of the shrubs for accumulation of radionuclides in their biomass were estimated based on the calculated transfer factors (TFs). The leaves and berries of Rubus idaeus and Ribes nigrum had the highest TFs for ${ }^{137} \mathrm{Cs}$ (up to 0.029 ) (Table 1). The TFs for ${ }^{137} \mathrm{Cs}$ obtained for the berries of these species corresponded to the previous data of field investigations (0.020-0.034) [2]. In the branches, ${ }^{137} \mathrm{Cs}$ TF was not higher than 0.009 . Of the studied isotopes, ${ }^{90} \mathrm{Sr}$ is the element best accumulated by Ribes nigrum: its TFs reach 1.9 in the leaves, 0.9 in the branches, and 0.25 in the berries, and they are similar to ${ }^{137} \mathrm{Cs}$ TFs in the mushrooms collected in the same area $[2,4]$. The comparatively low ${ }^{90} \mathrm{Sr}$ TFs in the berries of Ribes nigrum correspond to the data on Chernobyl fallouts (0.26-0.66) [5]. Based on the calculated TFs, we constructed the following sequences of ${ }^{137} \mathrm{Cs}$ and ${ }^{90} \mathrm{Sr}$ accumulation by different organs of the shrubs: "branches < leaves $\leq$ berries" and "berries < branches < leaves", respectively [2]. The highest ${ }^{238} \mathrm{U}$ TFs in the shrubs were recorded in the branches of Ribes nigrum and Rubus idaeus. The range of ${ }^{238} \mathrm{U}$ TFs $(0.004-0.018)$ overlaps the range of ${ }^{137} \mathrm{Cs}$ TFs $(0.006-0.027)$ (Table 1).

In the aboveground phytomass of Ribes nigrum, transuranic elements are mostly accumulated in the leaves and berries. Based on the calculated TFs (Table 2), we obtained the following sequences of ${ }^{243,244} \mathrm{Cm}$ and ${ }^{239,240} \mathrm{Pu}$ accumulation by different organs of the blackcurrant shrubs: "branches $<$ berries $<$ leaves" and "branches < leaves < berries", respectively. For the aboveground parts of Ribes nigrum, TFs for transuranic radionuclides (0.01-0.056) are similar to or higher than the TFs for ${ }^{238} \mathrm{U}$ and ${ }^{137} \mathrm{Cs}$. The previously published data [6,7] suggest that the TFs for Pu and Am are an order of magnitude lower than the TFs for ${ }^{137} \mathrm{Cs}$. The higher TFs of transuranic elements obtained in our study may be caused by the different routes of entry of transuranic radionuclides to the soil in the study area.

Thus, the non-uniform distribution of radionuclides in the soil and the comparable TF values for ${ }^{137} \mathrm{Cs}$ and transuranic radionuclides suggest a conclusion that plants growing at certain sites can be expected to contain higher activity concentrations of transuranic elements. Also, the behavior of transuranic elements in ecosystems is not sufficiently understood so far. Therefore, the problems in their 
Table 2. Transfer factors of transuranic radionuclides to different parts of Ribes nigrum for the site "Atamanova (island)."

\begin{tabular}{|l|c|c|c|}
\hline TFs & ${ }^{239,240} \mathrm{Pu}$ & ${ }^{241} \mathrm{Am}$ & ${ }^{243,244} \mathrm{Cm}$ \\
\hline Roots & 0.027 & 0.051 & 0.073 \\
\hline Branches & 0.010 & 0.025 & 0.018 \\
\hline Leaves & 0.026 & 0.051 & 0.045 \\
\hline Berries & 0.056 & <DL & 0.027 \\
\hline
\end{tabular}

determination should not impede the progress of the studies on the distribution of these elements in ecosystems.

\section{References}

[1] Bolsunovsky A. and Bondareva L., J. Alloy. Compd. 444-445 (2007) 495-499.

[2] Bolsunovsky A.Ya., Dementyev D.V., Radioprotection 5(44) (2009) 115-120.

[3] Bolsunovsky, A., Ermakov, A. \& Sobolev, A. (2007). Radiochim. Acta. 95(9) 547-552.

[4] Bolsunovsky A.Ya., Dementyev D.V., Bondareva L.G., Radiatsionnaya biologiya. Radioekologiya (Radiation Biology. Radioecology), 1(46) (2006) 67-74. (In Russian)

[5] Lux D., Kammerer L., Ruhm W., Wirth E., Sci. Total Environ 173/174 (1995) 375-384.

[6] Carini F., J. Environ. Radioactivity 52 (2001) 237-279.

[7] Green N., Wilkins B. T., Hammond D. J. (1997). J. Radioanal Nucl Ch 226(1-2) 195-200. 